\title{
Laparoscopıc Fundoplication with Prosthetic Hiatal Closure
}

\author{
Ahmet Turkcapar · Ilknur Kepenekci • \\ Hatim Mahmoud · Acar Tuzuner
}

Published online: 2 October 2007

(c) Société Internationale de Chirurgie 2007

\section{Erratum to: World J Surg}

DOI 10.1007/s00268-007-9066-7

In the above-mentioned article, published in SpringerLink on July 3, 2007, three of the four author's names were inadvertently omitted. The correct list of authors is shown above. Per PubMed and SpringerLink regulations, the online and print versions of all articles must exactly duplicate each other. Therefore, the authors' names are omitted from the print article, which appears in this issue following the Erratum.

We would like to extend our sincere apology to the authors for this error.
The online version of the original article can be found under doi: 10.1007/s00268-007-9066-7.

\footnotetext{
A. Turkcapar · I. Kepenekci $(\bowtie) \cdot$ H. Mahmoud · A. Tuzuner Department of General Surgery, Ankara University School of Medicine, AUTF Ibni Sina Hastanesi Ek Bina K4 Samanpazar, Ankara 06100, Turkey

e-mail: ilknurkpn@yahoo.com
} 